\title{
Association between the PSMB5 and PSMC6 genetic variations and children obesity in the Latvian population
}

\author{
N. Paramonova ${ }^{1}$, S. Kupca ${ }^{2,3}$, I. Rumba-Rozenfelde ${ }^{2,3}$, N. Sjakste ${ }^{2,4}$, T. Sjakste ${ }^{1}$ \\ ${ }^{1}$ Genomics and Bioinformatics, Institute of Biology of the University of Latvia \\ 3, Miera Str., Salaspils, Latvia, LV2169 \\ ${ }^{2}$ Faculty of Medicine, University of Latvia \\ 19, Raina Bulv., Riga, Latvia, LV1586 \\ ${ }^{3}$ University Children Hospital \\ 20, Juglas Str., Riga, Latvia, LV-1079 \\ ${ }^{4}$ Latvian Institute of Organic Synthesis \\ 21, Aizkraukles Str., Riga, Latvia, LV1006 \\ natasa@email.lubi.edu.lv
}

\begin{abstract}
According to the recent data the ubiquitin-proteasome system (UPS) is implicated in the pathogenesis of obesity. Aim of our study was to evaluate a possible association between genetic variations in the PSMB5 and PSMC6 genes and childhood obesity in the Latvian population. Methods. The rs11543947 (PSMB5), rs2295826 and rs2295827 (PSMC6) were genotyped in 94 overweight children versus 191 controls. Stratification was made by family history and sex. Results. Heterozygous genotype at rs 11543947 (PSMB5) manifested association with the disease $(P<0.01)$ in total group and in patients with family history $(O R=2.445[95 \%$ CI 1.378-4.339] and OR= $=2.746[95 \%$ CI 1.427-5.283], respectively). This genotype was observed more frequently $(P<0.05)$ in males with family obesity and in females without family history $(P<0.01)$. The heterozygotes at rs2295826 and $r s 2295827$ showed association $(P<0.01)$ in obesity $(O B)$, in patients with family history $(O R=2.119[95 \% C I$ $1.207-3.718]$ and $O R=2.379$ [95\% CI 1.249-4.533], respectively) and in males group. The rs11543947/ rs2295826-rs2295827 multi locus genotype heterozygous at all the studied loci and the haplotype represented by the rare alleles were more frequent in obese children when compared to controls $(P<0.001$ and $P=0.0001$ respectively). Conclusions. Genetic variations of the PSMB5 (rs11543947) and PSMC6 (rs2295826 and rs2295827) genes can influence childhood obesity in Latvians.
\end{abstract}

Keywords: PSMB5, PSMC6, SNPs, obesity, familial obesity, genotype-sex interaction.

Introduction. The ubiquitin-proteasome system (UPS) has been recently shown to be implicated in the pathogenesis of obesity (OB). It has been demonstrated that plasma ubiquitin and proteasome levels inversely correlated with a male body mass index in Southern Taiwan and Japanese population $[1,2]$ and that the proteasome dysfunction mediated the obesity-induced endoplasmic reticulum stress and insulin resistance in the liver [3]. A significant association was found between genetic variants of the PSMD9 gene and obesity-associated phenotypes in Italians [4]. The mutation in the PSMB8

(C) Institute of Molecular Biology and Genetics, NAS of Ukraine, 2014 gene has been reported to be associated with the autoinflammatory syndrome with lipodystrophy in Japanese [5]. Earlier we have detected the association of the $P S M A 3$ gene polymorphisms with susceptibility to obesity in Latvian children [6].

The current study was aimed to elucidate whether the single nucleotide polymorphisms (SNPs) of the PSMB5 (rs11543947) and PSMC6 (rs2295826 and rs2295827) genes are associated with the children obesity in the Latvian population.

Materials and methods. Case/control groups (94 obese children and 191 controls, respectively) were described previously $[6,7]$. The rs 2295826 and rs2295827 
genotyping data for controls were extracted from Sjakste et al. [7] and used in current study for the association analysis. The study was approved by the Central Medical Ethics Commission of the Latvian Ministry of Health.

The PSMB5 (rs11543947) and PSMC6 (rs2295826, rs2295827) genotyping procedures and analysis of amplified and digested products were the same as published previously $[7,8]$.

Single loci (SLGs) and multi locus rs11543947/ rs2295826-rs2295827 genotypes and alleles' frequencies were estimated by direct gene counting. The deviations from the Hardy-Weinberg equilibrium and association/correlation analyses were tested by the $\chi^{2}$ test (allele, multi-loci genotype frequencies, recessive and dominant, over dominant and multiplicative models) using PAST (version 3.03) software for Windows [9]. Only $2<$ OR $<0.5$ was considered to be clinically significant. DnaSP version 5 (http://www.ub.es/dnasp, [10]) was used to reconstruct the haplotypes from un-phased genotypes, and to evaluate the nucleotide and haplotype genetic diversity and pairwise linkage disequilibrium (LD) between the loci ( $\mathrm{D}^{\prime}$ and $\mathrm{r}^{2}$ ). Stratification was performed by the sex and obesity family history.

Results and discussion. In both cases and controls genotyping call rate was $100 \%$. Homozygotes on common alleles for all loci were observed more frequently in controls than obese patients (more than $80 \%$ and less than $70 \%$, respectively) and the tendencies were similar in children with and without family history (Table). The dominant and multiplicative models [11] were the most informative to reveal OB susceptible genotypes and alleles, respectively.

The rs11543947 heterozygous genotype showed a modest $(\mathrm{P}<0.01)$ association with $\mathrm{OB}$ risk in total group and in children with familial OB. A rare T allele was observed more frequently $(\mathrm{P}<0.05)$ in both these groups than in controls. The rs2295826 and rs2295827 loci alleles in OB patients were found to be in full linkage ( $\left(\mathrm{D}^{\prime}=\right.$ $\left.=1 ; \mathrm{r}^{2}=1\right)$, as it was previously reported for Latvian controls [7]. These loci heterozygous genotypes were found to be in association $(\mathrm{P}<0.01)$ with $\mathrm{OB}$ and familial OB groups. Rare alleles manifested nominal association with the disease $(\mathrm{P}<0.05)$.

The family background was found to be an obesity risk factor $(\mathrm{OR}=1.86$ for mother; $\mathrm{OR}=2.98$ for sib- lings) among Chinese male youths [12]. A significant difference $(\mathrm{p}<0.01)$ was observed between the subjects having the obesity family history and non-obese controls in rs 2348071 heterozygous genotype frequencies at the PSMA3 locus [6]. Bennet et al. have shown [13] that a greater predisposition to diabetes in Middle Eastern immigrants may be explained by a more extensive family history of the disorder.

In the current association study an interaction between sexes and familial obesity was revealed. The rs 11543947 risk CT genotype and rare T allele were found more frequently in males with family obesity $(\mathrm{P}<$ $0.05)$ and in females without family history $(\mathrm{P}<0.01)$. The rs2295826 and rs2295827 heterozygous genotypes and minor alleles were associated $(\mathrm{P}<0.01$ and $\mathrm{P}<$ 0.05 , respectively) with all OB subgroups in males.

Sex specific differences in incidence and severity are also well known features for epidemiology of obesity. The sex-influenced association of obesity with genetic variations at the LYPLAL1 locus, which encodes a lipase/esterase expressed in adipose tissue was suggested [14]. Seven new loci exhibited marked sexual dimorphism with a stronger effect on weight-hip ratio in women than men ( $\mathrm{P}$ for sex difference $<0.05$ to $\mathrm{P}<$ 0.0001) [15].

Thus, our data on the importance of interactions between the family history and sex for susceptibility for childhood obesity confirm the previous reports. Obviously having in our disposition a collection of a relatively small number of samples we can't reach high statistical reliability of results. The small number of subjects and the wide range of values (reflected by large standard deviation) precluded reliable statistical confirmation of this admission. However, even a study with small subject number reveals the trend on the association of the disease and can predict the common trends of association also for larger sample groups collected in larger populations.

The rs11543947/rs2295826-rs2295827 three locus genotype heterozygous at all the loci involved was found about four times more frequently in OB patients than in controls (about 3 and $13 \%$, respectively) and showed to be OB susceptible $(\mathrm{P}<0.001)$. The multi locus $\mathrm{T} / \mathrm{G}-\mathrm{T}$ haplotype represented by rare alleles of the studied loci was more frequent $(\mathrm{P}=0.0001)$ in obese children when compared to controls ( 0.5 and $6 \%$, respectively). 
CHILDHOOD OBESITY ASSOCIATED WITH PSMB5 AND PSMC6 POLYMORPHISMS

SNPS association with childhood obesity in common cohort, with and without family history groups

\begin{tabular}{|c|c|c|c|c|c|c|c|c|}
\hline \multirow{2}{*}{ Gene/SNP ID } & \multirow{2}{*}{ MA/Genotype } & \multicolumn{4}{|c|}{ Number (frequency \%) } & \multicolumn{3}{|c|}{ Statistically significant association } \\
\hline & & Control, $n=191$ & OB, $n=94$ & $\mathrm{FH}, n=59$ & $\mathrm{NFH}, n=32$ & $P$ & OR & {$[95 \% \mathrm{Cl}]$} \\
\hline \multirow[t]{7}{*}{ PSMB5/rs11543947 } & $\mathrm{T}$ & $34(8.90)$ & $31(16.49)$ & $21(17.80)$ & $10(15.63)$ & $<0.05^{\mathrm{OB}}$ & 2.021 & [1.247-3.391] \\
\hline & & - & - & - & - & $<0.05^{\mathrm{FH}}$ & 2.216 & [1.236-3.971] \\
\hline & & - & - & - & - & $>0.05^{\mathrm{NFH}}$ & - & - \\
\hline & $\mathrm{CC}$ & $159(83.25)$ & $63(67.02)$ & $38(64.41)$ & $22(68.75)$ & - & - & - \\
\hline & $\mathrm{CT}$ & $30(15.71)$ & $31(32.98)$ & $21(35.59)$ & $10(31.25)$ & $<0.01^{\mathrm{OB}}$ & 2.445 & [1.378-4.339] \\
\hline & & - & - & - & - & $<0.01^{\mathrm{FH}}$ & 2.746 & [1.427-5.283] \\
\hline & TT & $2(1.04)$ & No & No & No & - & - & - \\
\hline \multirow{8}{*}{$\begin{array}{l}P S M C 6 / \mathrm{rs} 2295826- \\
\mathrm{rs} 2295827\left(\mathrm{D}^{\prime}=1\right. \\
\left.\mathrm{r}^{2}=1\right)^{*}\end{array}$} & G & $40(10.47)$ & $33(17.55)$ & $22(18.64)$ & $10(15.63)$ & $<0.05^{\mathrm{OB}}$ & 1.820 & [1.109-2.987] \\
\hline & & - & - & - & - & $<0.05^{\mathrm{FH}}$ & 1.959 & [1.116-3.439] \\
\hline & & - & - & - & - & $>0.05^{\mathrm{NFH}}$ & - & - \\
\hline & AA & $155(81.15)$ & $63(67.02)$ & $38(64.41)$ & $23(71.88)$ & - & - & - \\
\hline & AG & $32(16.75)$ & $29(30.85)$ & $20(33.90)$ & $8(25.00)$ & $<0.01^{\mathrm{OB}}$ & 2.119 & [1.207-3.718] \\
\hline & & - & - & - & - & $<0.01^{\mathrm{FH}}$ & 2.379 & [1.249-4.533] \\
\hline & & - & - & - & - & $>0.05^{\mathrm{NFH}}$ & - & - \\
\hline & GG & $4(2.10)$ & $2(2.13)$ & $1(1.69)$ & $1(3.13)$ & - & - & - \\
\hline Loci & L1/L2-L3 & - & - & - & - & - & - & - \\
\hline $\begin{array}{l}\text { Heterozygous } \\
\text { genotypes }\end{array}$ & CT/AG-CT & $5(2.62)$ & $12(12.77)$ & $7(11.86)$ & $5(15.63)$ & $<0.001^{\mathrm{OB}}$ & 9.018 & [2.967-27.410] \\
\hline Rare alleles haplotype & $\mathrm{T} / \mathrm{G}-\mathrm{T}$ & $2(0.52)$ & $11(5.85)$ & $7(5.93)$ & $4(6.25)$ & $0.0001^{\mathrm{OB}}$ & 13.660 & [2.895-62.524] \\
\hline
\end{tabular}

$\mathrm{N}$ o t e. OB patients were represented by 59 children with obesity family history, 32 children without family history and there were no data on familial history of obesity in 3 cases. Abbreviations: OB - Obesity; FH - obesity with family history; NFH - obesity without family history. *Alleles and genotypes frequencies of the rs 2295826 and rs2295827 were found in full linkage. L1/L2-L3 corresponds to the rs 11543947 and rs2295826-rs2295827 loci respectively.

Susceptibility of genes encoding proteasome subunits to the immunity related disorders was studied previously in Latvians. The rs1048990 (PSMA6), rs2295826 and rs2295827 (PSMC6), rs2348071 (PSMA3) were found to be associated with susceptibility to bronchial asthma [16]. The rs2277460 (PSMA6), rs2295826 and rs2295827 (PSMC6) and rs2348071 (PSMA3) manifested association with juvenile idiopathic arthritis [8]. The rs2348071 (PSMA3) was found to be associated with multiple sclerosis [17] and childhood obesity [6].

Obesity in the young characterized by visceral fat accumulation has been shown to be a major risk factor for adult-onset type 2 diabetes mellitus [18, 19], therefore, we cannot exclude in our cases a possibility of the development of diabetes in adult age.
Conclusions. The genetic variation of PSMB5 (rs11543947) and PSMC6 (rs2295826 and rs2295827) $14 \mathrm{q}$ proteasomes subunits can influence OB in Latvians.

Acknowledgements \& Funding. This study was supported by the Latvian National Research Program «Biomedicine 2014».

Асоціація між генетичними варіантами PSMB5 і PSMC6

та дитячим ожирінням 3-поміж жителів Латвії

Н. Парамонова, С. Купча, И. Румба-Розенфелде,

Н. Сьяксте, Т. Сьяксте

Резюме

Згідно з останніми даними, убіквітин-залежна протеасомна система бере участь у патогенезі ожиріння. Мета. Оцінити можливий зв'язок між генетичними варіантами протеасомних генів PSMB5 і PSMC6 та схильністю до захворювання дитячим ожирін- 
ням у Латвійській популяиии. Методи. Локуси гs 11543947 (PSMB5), rs2295826 i rs2295827 (РSMC6) генотипували у 94 дітей з надлишковою вагою і у 191 здорового індивіда. Оиінку проводили за асоиіацією з ожирінням як таким, за сімейною історією та за статтю. Результати. Гетерозиготний генотип, який належить до локусу rs11543947 (PSMB5), виявився помірно асоиійованим ( $P<$ 0,01) із захворюванням як таким $i$ з ожирінням з сімейною історією (співвідношення шансів СШ =2,445 [95\% ДІ 1.378-4.339] $i$ $С Ш=2,746$ [95 \% ДІ 1.427-5.283] відповідно). Цей генотип найчастіше спостерігався у чоловіків із сімейною історією ожиріння $(P<0,05)$ та у жінок без сімейної історії $(P<0,01)$. Гетерозиготні генотипи по локусах rs2295826 i rs 2295827 знайдено в помірній асоиіації $(P<0,01)$ в основній групі захворювання і у пацієнтів з сімейною історією (СШ =2,119 [95\% ДІ 1.207-3.718] $і$ СШ = $=2,379$ [95 \% ДІ 1.249-4.533] відповідно), а також у чоловіків. Багатолокусний генотип rs11543947/rs2295826-rs2295827, представлений гетерозиготами по всіх локусах, і гаплотип, представлений рідкісними алелями, були найчастішими у групі хворих на ожиріння порівняно з контрольною групою $(P<0,001$ і $P=0,0001$ відповідно). Висновки. Генетичні варіації локусів PSMB5 (rs 11543947) i PSMC6 (rs2295826 i rs2295827) можуть впливати на схильність до захворювання ожирінням у детей Латвійської популяиії.

Ключові слова: PSMB5, PSMC6, SNPs, ожиріння, сімейне ожиріння, взаємодія генотип-стать.

Ассоциация между генетическими вариантами PSMB5 и PSMC6 и детским ожирением среди жителей Латвии

Н. Парамонова, С. Купча, И. Румба-Розенфелде,

Н. Сьяксте, Т. Сьяксте

Резюме

Согласно последним данным, убиквитин-зависимая протеасомная система участвует в патогенезе ожирения. Цель. Оиенить возможную связь между генетическими вариантами протеасомных генов PSMB5 и PSMC6 и подверженностью заболеванию детским ожирением в Латвийской популяции. Методы. Локусы rs11543947 (PSMB5), rs2295826 и rs2295827 (PSMC6) генотипировали у 94 детей с избыточным весом и у 191 здорового индивида. Оиенку проводили по ассоциации с ожирением как таковым, с семейной историей и с полом. Результаты. Гетерозиготный генотип, относящийся к локусу rs 11543947 (PSMB5), оказался умеренно ассоииированным $(P<0,01)$ с заболеванием как таковым и с ожирением с семейной историей (отнотение шансов ОШ = $=2,445[95 \%$ ДИ 1.378-4.339] и ОШ $=2,746$ [95\% ДИ 1.4275.283] соответственно). Этот генотип наиболее часто наблюдался у мужчин с семейной историей ожирения $(p<0,05)$ и уженщин без семейной истории $(P<0,01)$. Гетерозиготные генотипь по локусам rs2295826 и rs2295827 найдены в умеренной ассоичаиии $(P<0,01)$ в основной группе заболевания и у пачиентов с семейной историей (ОШ = 2,119 [95\% ДИ 1.207-3.718] и ОШ = = 2,379 [95\% ДИ 1.249-4.533] соответственно) и у мужчин. Многолокусный генотип rs11543947/rs2295826-rs2295827, представленный гетерозиготами по всем локусам, и гаплотип, представленный редкими аллелями, были наиболее частыли в группе больных ожирением по сравнению с контрольной группой $(P<0,001$ u $P=0,0001$ соответственно). Выводы. Генетические вариации локусов PSMB5 (rs 11543947) и PSMC6 (rs2295826 и rs2295827) могут влиять на подверженность заболеваемости ожирением у детей в Латвийской популяции.

Ключевые слова: PSMB5, PSMC6, SNPs, ожирение, семейное ожирение, взаимодействие генотип-пол.

\section{REFERENCES}

1. Chang TL, Chang CJ, Lee WY, Lin MN, Huang YW, Fan $K$. The roles of ubiquitin and $26 \mathrm{~S}$ proteasome in human obesity. Metabolism. 2009;58(11):1643-8.

2. Sakamoto K, Sato Y, Sei M, Ewis AA, Nakahori Y. Proteasome activity correlates with male BMI and contributes to the differentiation of adipocyte in hADSC. Endocrine. 2010;37(2):274-9.

3. Otoda T, Takamura T, Misu H, et al. Proteasome dysfunction mediates obesity-induced endoplasmic reticulum stress and insulin resistance in the liver. Diabetes. 2013;62(3):811-24.

4. Gragnoli $C$. Overweight condition and waist circumference and a candidate gene within the 12q24 locus. Cardiovasc Diabetol. 2013;12:2.

5. Kitamura A, Maekawa Y, Uehara H, et al. A mutation in the immunoproteasome subunit PSMB8 causes autoinflammation and lipodystrophy in humans. J Clin Invest. 2011;121(10):4150-60.

6. Kupca S, Sjakste T, Paramonova N, et al. Association of obesity with proteasomal gene polymorphisms in children. J Obes. 2013; 2013:638154.

7. Sjakste T, Paramonova N, Wu LS-S, et al. PSMA6 (rs2277460, rs1048990), PSMC6 (rs2295826, rs2295827) and PSMA3 (rs2348071) genetic diversity in Latvians, Lithuanians and Taiwanese. Meta Gene. 2014;2:283-98.

8. Sjakste T, Paramonova N, Rumba-Rozenfelde I, Trapina I, Sugoka $O$, Sjakste $N$. Juvenile idiopathic arthritis subtype- and sex-specific associations with genetic variants in the PSMA6/PSMC6/ PSMA3 gene cluster. Pediatr Neonatol. 2014;55(5):393-403.

9. Hammer Q, Harper D, Ryan P. Past: Paleontological Statistics software packarge for education and data analysis. Paleontologija Electronica. 2001; 4(1):9pp

10. Rozas J. DNA sequence polymorphism analysis using DnaSP. Methods Mol Biol. 2009;537:337-50.

11. Lewis $C M$. Genetic association studies: design, analysis and interpretation. Brief Bioinform. 2002;3(2):146-53.

12. Shi H, Jiang B, Wei Sim JD, Chum ZZ, Ali NB, Toh MH. Factors associated with obesity: a case-control study of young adult Singaporean males. Mil Med. 2014;179(10):1158-65.

13. Bennet $L$, Lindblad $U$, Franks $P W$. A family history of diabetes determines poorer glycaemic control and younger age of diabetes onset in immigrants from the Middle East compared with native Swedes. Diabetes Metab. 2014. pii: S1262-3636(14)00136-0.

14. Benjamin AM, Suchindran S, Pearce K, et al. Gene by sex interaction for measures of obesity in the framingham heart study. J Obes. 2011;2011:329038.

15. Heid IM, Jackson AU, Randall JC, et al. Meta-analysis identifies 13 new loci associated with waist-hip ratio and reveals sexual dimorphism in the genetic basis of fat distribution. Nat Genet. 2010;42(11):949-60.

16. Paramonova N, Wu L. Shi-Shin, Rumba-Rozenfelde I, Wang J-Y, Sjakste N, Sjakste T. Genetic variants in the PSMA6, PSMC6 and PSMA3 genes associated with childhood asthma in Latvian and Taiwanese populations. Biopolym Cell. 2014; 30(5):377-87.

17. Kalnina J, Paramonova N, Sjakste N, Sjakste T. Study of association between polymorphisms in the PSMB5 (rs11543947) and PSMA3 (rs2348071) genes and multiple sclerosis in Latvians. Biopolym Cell. 2014; 30(4):305-9.

18. Kaufman $F$. Type 2 diabetes mellitus in children and adolescents: the new epidemic. Obesity in Childhood and Adolescence. Eds W. Keiss, C. Marcus, M. Wabitsch. New Jersey, Karger publ., 2004: 183-4.

19. de Luca C, Olefsky JM. Stressed out about obesity and insulin resistance. Nat Med. 2006;12(1):41-2.

Received 01.10.14 